Медіафорум : аналітика, прогнози, інформаційний менеджмент : зб. наук. праць. - Чернівці :

Чернівецький нац. ун-т, 2021. -

Том 9. - C. 194-206
Mediarorum: Analytics, Forecasts, Information Management: Collection of Research Articles. - Chernivtsi: Chernivtsi National University, 2021. Vol. 9. - pp. 194-206

https://doi.org/10.31861/mediaforum.2021.9.194-206

УДК: 323+330.837]:061.1€С

(c) Ruslana Klym ${ }^{1}$

\title{
THEORETICAL AND METHODOLOGICAL FEATURES OF EUROPEANIZATION AND NEW INSTITUTIONALISM
}

It is identified in the paper that one of the important prerequisites for implementing an effective European integration policy is to consider the theories of Europeanization and new institutionalism. The essence of the concepts of «Europeanization» and "new institutionalism» is studied, the evolution of theoretical approaches to their research is considered, and the directions of studying «external» Europeanization were analyzed. The paper proves that the concept of Europeanization is widely used in the European scientific literature to analyze the political and regulatory influence of the European Union on new EU member states and neighboring countries, as well as the fundamental mechanisms of Europeanization. The author notes that Europeanization implies changes, transformations, and reforms taking place in all spheres of life under the influence of European integration processes, which can be analyzed from the standpoint of new institutionalism. The key provision of the new institutionalism is defined by the commonly used expression - «institutions matter», whose analytical priorities are to use a wide range of interdisciplinary approaches to the analysis of norms, institutions and processes.

Keywords: Europeanization, "external" Europeanization, European Union, new institutionalism.

\section{Теоретико-методологічні особливості європеїзації та неоінституціоналізму}

У статті автор наголошує, що однією із важливих передумов впровадження ефективної політики європейської інтеграції є розгляд теорій європеїзації та неоінституиіоналізму. Досліджено сутність

1 Аспірантка кафедри політології та державного управління Чернівецького національного університету імені Юрія Федьковича, Україна. ruslana_klym@ukr. net; http://orcid.org/0000-0001-8305-3949 
понять «європеїзація» та «неоінституціоналізм», розглянуто еволюцію теоретичних підходів до їх дослідження, проаналізовано напрями вивчення «зовнішньої» європеїзації. З'ясовано, що концепція європеїзачії широко використовується в європейській науковій літературі для аналізу політичного і нормативного впливу Європейського Союзу на нові краӥни-члени ЄС та сусідні держави, а також фундаментальних механізмів європеїзаціі. Визначено, що європеїзація - це зміни, трансформації, реформи, що відбуваються у всіх сферах життя під впливом процесів європейської інтеграції, які можна проаналізувати з позицій неоінституціоналізму. Зазначено, що неоінституціоналізм постає в сучасній політичній науці не як протиставлення «старому» інституиіоналізму, а як його розвиток, доповнений новими ідеями та пізнавальними можливостями. Ключове положення нового інституціоналізму визначається загальновживаним виразом - «інституиіі мають значення», а аналітичні пріоритети якого полягають у використання широкого комплексу міждисииплінарних підходів до аналізу норм, інститутів та проиесів.

Ключові слова: європеїзація, «зовнішня» європеӥзація, Європейський Союз, неоінституціоналізм.

Statement of the scientific problem and its significance. Understanding the essence of modern European integration processes is impossible without considering the theories of Europeanization and new institutionalism, the scientific justification of which is one of the important prerequisites for implementing an effective European integration policy.

Analysis of recent research and publications. Problems of Europeanization were studied by R. Ladrech, B. Kohler-Koch, M. Lendjel, C. Radaelli, K. Featherstone, G. Kazamias, D. Mikhel, F. Schimmelfennig, U. Sedelmeier, M. Emerson and G. Noutcheva. New institutionalism is presented in the works of J. March, J. Olsen, A. Kolodiy, K. von Beyme, O. Stoiko, G. Peters, P. DiMaggio, P. Hall, R. Taylor, S. Babukhina and T. Savelyeva.

Purpose and objectives of the article. The purpose of the article is to analyze the theories of Europeanization in the context of new institutionalism. To achieve this goal, the author sets the task to ascertain the essence of the concepts of «Europeanization» and «new institutionalism», to consider the evolution of theoretical approaches to their research, to analyze the directions of studying «external» Europeanization. 
Presentation of the main material. In 1994, British scientist R. Ladrech proposed one of the first definitions of the concept of «Europeanization» and defined it as «the incremental process that reorients the direction and forms of (internal) policies, to the degree that European political and economic dynamics become part of the organizational (constructive) logic of national politics and policy-making» [Ladrech, 2001, 2]. B. Kohler-Koch defines Europeanization as the extension of the European political space, ideas, values and traditions outside the EU member states, pointing out the extension of this concept to non-EU states [Kohler-Koch, 1999, 15]. M. Lendjel characterizes Europeanization as the process of formation of supranational institutions, the formation of the practice of European multi-level governance practice and national institutional configurations under the influence and pressure of the EU [Lendjel, 2012, 37-38]. C. Radaelli describes Europeanization as «the complex process of construction, diffusion, and institutionalization of formal and informal rules, procedures, policy paradigms, styles, 'ways of doing things', and shared supplies and norms which are first defined and consolidated in the making of EU public policy and then incorporated into the logic of domestic discourse, identities, political structures, and public policies» [Radaelli, 2000].

K. Featherstone and G. Kazamias propose to consider Europeanization at three levels, in particular the first - the EU level, which implies expanding the power competence of the union, coordination of the foreign poli$\mathrm{cy}$ and measures to ensure the security of the continent. The second one is the institutional level that operates at the level of national states - subjects of the European Union, and should incorporate legislation, government regulations, ethnic and cultural characteristics, as well as the interests of countries. The third level extends beyond the EU and covers the states that are not members of the union, but are closely related to it. In their opinion, the analysis of the phenomenon of Europeanization should focus on the following: institutional adaptation of government bodies to the EU policies and strategy; expansion of the rights and powers of the political process subjects at the level of individual states - civil society and technocratic elites in particular; regulation of macroeconomic processes; changes in the political system; the impact on the national identity of residents of the European Union; strategic resources for the implementation of foreign policy interests [Featherstone and Kazamias, 2001, 15-16].

Also, for a better understanding of the Europeanization process, it is advisable to consider its dimensions identified according to the criterion 
of the object of change. According to D. Mikhel, there are at least five possible dimensions of this process: first, the change in external borders. Europeanization in this dimension involves the territorial expansion of the European governance system and the degree of transformation of the European continent into a single political space; secondly, the development of government institutions at the EU level. Europeanization in this dimension means the development of a political decision-making center that would be capable of collective action, as well as providing a certain degree of political coordination and cohesion. Legitimate institutions and a respective regulatory framework strengthen the ability of authorities to make and implement binding decisions, as well as impose sanctions for non-compliance; third, expansion of the influence of the EU institutions on national and subnational regional and local governance systems. Europeanization here consists of the distribution of powers and responsibilities between different levels of government. All multi-level management systems need to find and establish a balance between unity and diversity, coordination from the center and local autonomy. Consequently, this dimension of Europeanization means the adaptation of national and subnational government systems to the political decision-making center (institutions) and EU legislation; fourth, the «export» of typical and EU-specific forms of political organization and governance outside the union. In this context, Europeanization touches upon the relations with third countries, their institutions and players, as well as the place and role of the EU in the world. With this in mind, Europeanization means forming a positive «export-import» balance with third countries, since they take more from the EU than vice versa, and the EU decisions have a greater impact on the international arena; fifth, a political project aimed at uniting and strengthening Europe politically [Mikhel, 2011, 23-24].

Modern researchers [Gawrich, Melnykovska and Schweickert, 2010, 1210] distinguish three statges of Europeanization (Membership Europeanization, Accession Europeanization and Neighborhood Europeanization), which respectively provide theoretical and methodological opportunities to describe the impact of the European Union on existing EU member states, analyze the prospects for membership in the community and determine the impact of the European Union on neighboring countries that do not have the prospect of joining the EU. It is also worth noting that the theoretical analysis of the Europeanization processes is developing in parallel with events and changes in the functioning of the EU 
at the practical level. If at first scientists studied Europeanization exclusively in connection with the process of deepening European integration, then as the largest expansion of the EU to the East in the history of the EU approached in 2004, the attention of scientists was increasingly focused on the study of the features of Europeanization of post-communist countries that set the strategic goal of integration into the EU and were soon invited to join [Prokopenko, Rudik and Bashtannik, 2010, 4], which led to the development of such a direction as «Accession Europeanization». The emergence of research on «Neighborhood Europeanization» is also connected to practical questions that arise in association to relations between the EU and the non-candidate states. «Neighborhood Europeanization» mainly focuses on the ability of the EU to shape the domestic development of these countries, as well as the ability of these countries to absorb the process of Europeanization, comply their norms and standards with the EU, and become part of the European space of shared values, attitudes and ways of doing things [Zolkina, 2013].

198 We believe it is expedient to study the main approaches used by

- Western researchers to determine the essence of «external» Europeanization. Thus, based on the analysis of the Europeanization of CEE candidate countries, F. Schimmelfennig and U. Sedelmeierdistinguish two dimensions of Europeanization [Schimmelfennig, 2012]. On the one hand, Europeanization can be EU-driven or domestically driven. Another dimension of Europeanization is its institutional logic, which, according to the theory of new institutionalism, can take the form of «logic of consequences» or «logic of appropriateness».

T. Diez, S. Stetter and M. Albert, in their study of the EU's influence on border conflicts, propose the concept of four pathways of EU impact. They distinguish between these pathways primarily depending on «whether the impact is generated by specific EU measures or whether it is the impact of integration processes without the direct involvement of EU actors.» In addition to this, the impact may be targeted at specific policies or have broader social implications. The first path is «Compulsory Impact», which consists of using specific measures, the policy of «carrots and sticks», in relation to specific policies. «Connective Impact» - is carried out through specific (mostly financial) measures that establish and maintain communication between the conflicting parties. Other pathways function indirectly. «EnablingImpact» implies that actors in a conflict situation increase their influence due to their connection with the EU's political programs and po- 
sitions. Finally,»Constructive Impact» leads to a radical reconstruction of identities as a result of the influence of European integration [Diez, Stetter and Albert, 2006, 570-575].

M. Emerson and G. Noutcheva note that the term «Europeanization» is used to understand political, economic and social transformations in the process of European integration, and especially in cases where states join the European Union after the change of an undemocratic (fascist or communist) regime, and in some cases after violent conflicts. They consider three types of mechanisms that interact synergistically in the process of Europeanization: first, legal obligations in the political and economic spheres arising from the criteria for EU membership and / or membership of the Council of Europe and accession to the Convention for the Protection of Human Rights and Fundamental Freedoms; second, objective changes in economic structures and interests of individuals as a result of integration with Europe; third, subjective changes in the beliefs, expectations and identity of individuals, which becomes the source of political will to adopt European norms in business, politics, and civil society [Emerson and Noutcheva, 2004].

It is worth noting that the process of Europeanization takes place with the participation of European and national institutions, so it can be analyzed using such a theoretical approach as new institutionalism. The emergence of new institutionalism dates back to the 1980-s and is associated with the publication of an article by J. March and J. Olsen «The New institutionalism: Organizational Factors in Political Life» [March and Olsen, 1984, 734-749]. Arguing the expediency of methodological renewal of political science, the researchers stressed that the period of «forgetting the institutions» contributed to the fact that the theoretical and methodological positions of the political science acquired a limited character and proved the need to overcome those patterns of political science that were provoked and fueled by the use of behavioralism and structural functionalism, in particular contextualism, reductionism, utilitarianism, functionalism, instrumentalism. However, the new institutionalism was proposed to be evaluated not as a fundamentally new methodology, but as «the search for alternative ideas that simplify the subtleties of empiricalwisdom in a theoretically useful way» [March and Olsen, 1984, 748], «a generalapproach to the study of political institutions, a set of theoretical ideas and hypotheses concerning the relations between institutional characteristics and political 
agency, their (institutional) performance and change» [March and Olsen, 2005, 9].

A. Kolodiy notes that new institutionalism is a new, but conservative theory in its content, as it confirms the rightness of conservatives in the fact that only tradition, continuance and consistency create a solid foundation for stable development, and also indicates the presence of revolutionaries who hope that by willpower, one can instantly give birth to a viable new order on the basis of a certain project [Kolodiy, 2010, 62].

$\mathrm{K}$. von Beyme also gives his description of the new institutional approach, comparing it with institutionalism. The scientist defines the institutional approach asthe «burdened with a taste of conservatism», somewhat simplified and mechanistic regarding the consideration of the system, and in turn, new institutionalism, in his opinion, operates with newer approaches, in addition, its main difference from institutionalism is that not everything is explained through institutions (it is assumed that there are always situations where»poorly fixed political processes» arise) 200 [Beyme, 2008, 135].

In general, the differences between the «old» and new institutionalism, according to O. Stoiko, were manifested in three dimensions [Stoiko, 2016, 30-31]. First, the «old» institutionalists took law and politics as a basis and went to the economic sphere, trying to study the problems of modern economic theory using the methods of other social sciences. In turn, new institutionalists are moving in the opposite direction: they study political science and legal problems using the methods of neoclassical economic theory using the methods of microeconomics and game theory. Secondly, traditional institutionalism was based mainly on the inductive method, and sought to move from individual cases to generalizations, as a result of which the general institutional theory was never formed. In turn, new institutionalism follows a deductive path - from the general principles of neoclassical economic theory to the explanation of specific phenomena of social life. Third,»old» institutionalism paid attention primarily to the actions of human collectives (usually trade unions and the government) to protect the interests of the individual, and new institutionalism puts an independent individual at the forefront who voluntarily and according to his interests decides which collectives are most beneficial.

So, the changes that occur in the new institutionalism in comparison with the «old» institutionalism are changes concerning the categorical and conceptual apparatus of research, its principles, levels, subject field, 
methods and procedure of analysis. It is worth noting that for supporters of the methodology of new institutionalism, the definitionof political institution proposed by J. Marchand J. Olsen has become basic: «an institution is a relatively enduringcollection of rules and organized practices, embedded in structures of meaning and resources that are relatively invariant in the face of turnover of individuals and relatively resistant to idiosyncratic preferences and expectations of individuals and changing external circumstances» [March and Olsen, 1984, 742].

The key axioms of the new institutionalism establish that: 1) political institutions appear as full actors of politics through the presence of their own interests; 2) institutions influence human behavior through the establishment of certain restrictions through rules; 3) institutions determine the results of politics and appear as its main determinants in defining the results of politics through the awareness of political actors of their goals [Beyme, 2008, 9].

Giving the classification of new institutionalism, G. Peters identified five main directions: 1) economic (normative) institutionalism, which focuses on a set of values that determine the behavior of members of the organization; 2) institutionalism from the point of view of the theory of rational choice, which interprets institutions as rules that allow them to accumulate and realize their interestsby imposing restrictions on the behavior of individuals; 3) historical institutionalism, for which the first institutional choice made many years ago, has a decisive influence on the modern political process; 4) social institutionalism, which studies the nature of interaction between different social groups, between the state and society; 5) structural functionalism, which aims to compare presidential and parliamentary regimes, federations and unitary states [Peters, 1999, 218]. P. DiMaggio identifies three «new institutionalisms»: institutionalism of rational action, social construction, and indirect conflict [Andrusiv, 2006, 19]. P. Hall and R. Taylor identified three main approaches to institutional analysis, namely sociological institutionalism, rational choice institutionalism, and historical institutionalism [Hall and Taylor, 1996, 936-957]. This heterogeneity and versatility of new institutionalism is explained by the peculiarities of its origin and use in political, economic, and sociological sciences, as well as differences in the conceptualization of the institutional context.

Among the opportunities that the theory of new institutionalism provides in modern political intelligence, according to S. Babukhina and 
T. Savelyeva, «we can name the following. First, it is the use of an interdisciplinary approach, which is the basis of new institutionalism (the use of economic, cultural and other scientific knowledge, theories), in understanding both institutions and systemic and non-systemic political phenomena and processes. Secondly, taking into account the current transition of «real» politics to the category of «symbolic» and the popularization of public policy, as well as modern characteristics of socio-political reality as unstable, fluid, etc., this approach helps to reveal not only the formal aspects of the functioning of the political process, but its real aspects both through a multi-level institutional analysis, and taking into account the informal components of the political process. Third, within the framework of new institutionalism, the range of research is expanding by involving not only the "primary» political institutionsin the analysis, but also the «secondary» ones, including informal ones. Fourth, through the prism of new institutionalism, it is possible to comprehend political phenomena and processes in a new way (for example, through their consideration as a practice, or taking into account transaction costs, or taking into account the influence of the institutional environment, etc.)» [Babukhina and Savelyeva, 2020, 14-15].

Conclusions. Therefore, we can conclude that the conceptual basis of research on the process of spreading European policies and institutions is the recognition by researchers of institutional changes as a «dependent variable» and the discussion of conditions that may influence internal or regional changes in response to the promotion of ideas, values and institutions of the European Union. Therefore, to study the processes of European integration, it is worth using such theoretical approaches as Europeanization and new institutionalism.

Modern researchers understand Europeanization as the extension of the EU's political and regulatory influence to new member states, as well as to the states of neighboring regions. This process takes place with the participation of both European institutions, national governments and local elites, so it can be analyzed from the standpoint of new institutionalism. The fundamental position of which is defined by the common expression - «institutions matter». The versatility of the new institutionalism is explained by the peculiarities of its origin and use in political, economic, and sociological sciences, the application of a wide range of interdisciplinary approaches to the analysis of norms, institutions, and processes, as well as differences in the conceptualization of the institutional context. 


\section{Джерела та література:}

1. Андрусів В. В. 2006. Інституційний інтерес: виникнення та стратегічне значення. Стратегічні пріоритети, № 1, С. 18-26.

2. Бабухіна С. А., Савельєва Т. П. 2020. Сучасні політичні дослідження у контексті неоінституціоналізму: стратегії наукових розвідок. Сучасне суспільство, №1 (20), С. 4-17.

3. Байме К. 2008. Політичні теорії сучасності. Київ: Стилос, 395 c.

4. Колодій А. 2010. Неоінституціоналізм та його пізнавальні можливості в політичних дослідженнях. Вісник Львівського ун-ту. Сер.: філософсько-політологічні студії, С. 60-69.

5. Лендьел М. О. 2012. Вплив процесів європеїзації на вдосконалення стандартів і практики управління у регіоні Центральної Європи. Стратегічні пріоритети, №1, С. 37-42.

6. Міхель Д. О. 2011. Визначення поняття процесу «європеїзація» та його вплив на сучасне суспільство. Наукові праці Чорноморського державного університету імені Петра Могили. Сер. Політологія, Т. 162, Вип. 150, С. 22-25.

7. Питерс Г., Гудин Р., Клингеманн Х.-Д. 1999. Политические институты: вчера и сегодня. Политическая наука. Новые направления. Москва: Вече, С. 218-231.

8. Прокопенко Л., Рудік О., Баштанник В. 2010. Процес європеїзації та його особливості в посткомуністичних країнах ЦСЄ: наук. розробка. К.: НАДУ, 36 с.

9. Стойко О.М. 2016. Трансформація політичних інститутів у сучасних перехідних суспільствах. Київ: Ін-т держави і права ім. В.М. Корецького НАН України, 416 с.

10. Diez T., Stetter S., Albert M. 2006. The European Union and Border Conflicts: The Transformative Power of Integration. International Organization, 60 (3), P. 563-593.

11. Emerson M., Noutcheva G. 2004. Europeanisation as a Gravity Model of Democratisation. CEPS Working Documents, 214 p.

12. Featherstone K., Kazamias G. 2001. Introduction: Southern Europe and the Process of «Europeanization». Europeanization and the southern periphery. London: FRANK CASS PUBLISHERS, 25 p.

13. Gawrich A., Melnykovska I., Schweickert R. 2010. Neighbourhood Europeanization Through ENP: The Case of Ukraine. Journal of Common Market Studies, Vol.48, № 5, P. 1209-1235. 
14. Hall P.A., Taylor R.C. 1996. Political science and the three new institutionalisms. Political Studies, Vol. 44, № 12, P. 936-957.

15. Kohler-Koch B. 1999. The evolution and transformation of European governance. The Transformation of Governance in the European Union. London: Routledge, P. 14-36.

16. Ladrech R. 2001. Europeanization and Political Parties: towards a Framework for Analysis. Keele European Parties Research Unit (SPRU). Working Paper 7, $16 \mathrm{p}$.

17. March J. G., Olsen J. P. 1984. The New Institutionalism: Organizational Factors in Political Life. American Political Science Review, Vol. 78, № 37, P. 734-749.

18. March J. G., Olsen J. P. 2005. «Elaborating the «new institutionalism», Working Paper. Centre for European Studies University of Oslo, March, № 11. http://www.unesco.amu.edu.pl/pdf/olsen2.pdf (accessed April, 06, 2021).

19. Radaelli Claudio M. 2000. Whither Europeanization? Concept 204 Stretching and Substantive Change. European Integration online Papers

- (EIoP), Vol. 4, No. 8. https://ssrn.com/abstract=302761 (accessed October, 24, 2021).

20. Schimmelfennig F. 2012. Europeanization beyond Europe. Living Reviews in European Governance, №1 (7). http://europeangovernance. livingreviews.org/ Articles/lreg-2012-1/ (accessed October, 24, 2021).

21. Zolkina M. The Impact of Europeanization on Democratic Transformations: The Cases of Slovakia and Ukraine. www.ivo.sk/ buxus/docs//rozne/ The_Impact_of_Europeanization_on_Democratic_ Transformations_Zolkina.pdf (accessed October, 24, 2021).

\section{References:}

1. Andrusiv V. V. 2006. Instytutsiinyi interes: vynyknennia ta stratehichne znachennia. Stratehichni priorytety, № 1, S. 18-26.

2. Babukhina S. A., Savelieva T. P. 2020. Suchasni politychni doslidzhennia $\mathrm{u}$ konteksti neoinstytutsionalizmu: stratehii naukovykh rozvidok. Suchasne suspilstvo, №1 (20), S. 4-17.

3. Beyme K. 2008. Politychni teorii suchasnosti. Kyiv: Stylos, 395 s.

4. Kolodii A. 2010. Neoinstytutsionalizm ta yoho piznavalni mozhlyvosti v politychnykh doslidzhenniakh. Visnyk Lvivskoho un-tu. Ser.: filosofsko-politolohichni studii, S. 60-69. 
5. Lendel M. O. 2012. Vplyv protsesiv yevropeizatsii na vdoskonalennia standartiv i praktyky upravlinnia u rehioni Tsentralnoi Yevropy. Stratehichni priorytety, №1, S. 37-42.

6. Mikhel D. O. 2011. Vyznachennia poniattia protsesu «ievropeizatsiia» ta yoho vplyv na suchasne suspilstvo. Naukovi pratsi Chornomorskoho derzhavnoho universytetu imeni Petra Mohyly. Ser. Politolohiia, T. 162, Vyp. 150, S. 22-25.

7. Piters G. Gudin R., Klingemann H.-D. 1999. Politicheskie institutyi: vchera i segodnya. Politicheskaya nauka. Novyie napravleniya. Moskva: Veche, S. 218-231.

8. Prokopenko L., Rudik O., Bashtannyk V. 2010. Protses yevropeizatsii ta yoho osoblyvosti v postkomunistychnykh krainakh TsSIe: nauk. rozrobka. K.: NADU, 36s.

9. Stoiko O.M. 2016. Transformatsiia politychnykh instytutiv u suchasnykh perekhidnykh suspilstvakh. Kyiv: In-t derzhavy i prava im. V.M. Koretskoho NAN Ukrainy, $416 \mathrm{s.}$

10. Diez T., Stetter S., Albert M. 2006. The European Union and 205 Border Conflicts: The Transformative Power of Integration. International Organization, 60 (3), P. 563-593.

11. Emerson M., Noutcheva G. 2004. Europeanisation as a Gravity Model of Democratisation. CEPS Working Documents, $214 \mathrm{p}$.

12. Featherstone K., Kazamias G. 2001. Introduction: Southern Europe and the Process of «Europeanization». Europeanization and the southern periphery. London: FRANK CASS PUBLISHERS, 25 p.

13. Gawrich A., Melnykovska I., Schweickert R. 2010. Neighbourhood Europeanization Through ENP: The Case of Ukraine. Journal of Common Market Studies, Vol.48, № 5, P. 1209-1235.

14. Hall P.A., Taylor R.C. 1996. Political science and the three new institutionalisms. Political Studies, Vol. 44, № 12, P. 936-957.

15. Kohler-Koch B. 1999. The evolution and transformation of European governance. The Transformation of Governance in the European Union. London: Routledge, P. 14-36.

16. Ladrech R. 2001. Europeanization and Political Parties: towards a Framework for Analysis. Keele European Parties Research Unit (SPRU). Working Paper 7, $16 \mathrm{p}$.

17. March J. G., Olsen J. P. 1984. The New Institutionalism: Organizational Factors in Political Life. American Political Science Review, Vol. 78, № 37, P. 734-749. 
18. March J. G., Olsen J. P. 2005. «Elaborating the «new institutionalism», Working Paper. Centre for European Studies University of Oslo, March, № 11. http://www.unesco.amu.edu.pl/pdf/olsen2.pdf (accessed April, 06, 2021).

19. Radaelli Claudio M. 2000. Whither Europeanization? Concept Stretching and Substantive Change. European Integration online Papers (EIoP), Vol. 4, No. 8. https://ssrn.com/abstract=302761 (accessed October, 24, 2021).

20. Schimmelfennig F. 2012. Europeanization beyond Europe. Living Reviews in European Governance, №1 (7). http://europeangovernance. livingreviews.org/ Articles/lreg-2012-1/ (accessed October, 24, 2021).

21. Zolkina M. The Impact of Europeanization on Democratic Transformations: The Cases of Slovakia and Ukraine.:www.ivo.sk/ buxus/docs//rozne/ The_Impact_of_Europeanization_on_Democratic_ Transformations_Zolkina.pdf (accessed October, 24, 2021). 